\title{
Correction to: Stress-free-state based structural analysis and construction control theory for staged construction bridges
}

Shunquan Qin ${ }^{1,2^{*}}$, Kai Wei ${ }^{2}$, Jingxi Qin ${ }^{3}$, Renan Yuan ${ }^{1,2}$, Leiping Xu ${ }^{1}$ and Qilian Dan ${ }^{2}$

The original article can be found online at https://doi. org/10.1186/s43251-020$00001-y$.

\section{*Correspondence:}

qinshq@cae.cn

${ }^{1}$ China Railway Major Bridge Reconnaissance \& Design Institute Co., Ltd., Wuhan 430050, China

Full list of author information is available at the end of the article

\section{Correction to: Adv Bridge Eng 1, 1 (2020) \\ https://doi.org/10.1186/s43251-020-00001-y}

After publication of this article (Qin et al., 2020), the authors reported that the Competing interests section in the back matter need to be changed to the below:

\section{Competing interests}

Author Shunquan Qin is Editor-in-Chief of Advances in Bridge Engineering.

The original article has been updated.

\section{Author details}

${ }^{1}$ China Railway Major Bridge Reconnaissance \& Design Institute Co., Ltd., Wuhan 430050, China. ${ }^{2}$ Department of Bridge Engineering, Southwest Jiaotong University, Chengdu 610031, China. ${ }^{3}$ Department of Civil and Environmental Engineering, University of California at Los Angeles, Los Angeles 90024, USA.

Published online: 11 October 2021

\section{Reference}

Qin S, Wei K, Qin J et al (2020) Stress-free-state based structural analysis and construction control theory for staged construction bridges. Adv Bridge Eng 1:1. https://doi.org/10.1186/s43251-020-00001-y author(s) and the source, provide a link to the Creative Commons licence, and indicate if changes were made. The images or other third party material in this article are included in the article's Creative Commons licence, unless indicated otherwise in a credit line to the material. If material is not included in the article's Creative Commons licence and your intended use is not permitted by statutory regulation or exceeds the permitted use, you will need to obtain permission directly from the copyright holder. To view a copy of this licence, visit http:// creativecommons.org/licenses/by/4.0/. 